\title{
Sodium amphibole in the post-glaucophane high-pressure domain: The role of eckermannite
}

DOI:

10.2138/am-2018-6399

\section{Document Version}

Accepted author manuscript

Link to publication record in Manchester Research Explorer

\section{Citation for published version (APA):}

Howe, H., Pawley, A. R., \& Welch, M. D. (2018). Sodium amphibole in the post-glaucophane high-pressure domain: The role of eckermannite. American Mineralogist, 103(6), 989-992. https://doi.org/10.2138/am-2018-6399

\section{Published in:}

American Mineralogist

\section{Citing this paper}

Please note that where the full-text provided on Manchester Research Explorer is the Author Accepted Manuscript or Proof version this may differ from the final Published version. If citing, it is advised that you check and use the publisher's definitive version.

\section{General rights}

Copyright and moral rights for the publications made accessible in the Research Explorer are retained by the authors and/or other copyright owners and it is a condition of accessing publications that users recognise and abide by the legal requirements associated with these rights.

\section{Takedown policy}

If you believe that this document breaches copyright please refer to the University of Manchester's Takedown Procedures [http://man.ac.uk/04Y6Bo] or contact uml.scholarlycommunications@manchester.ac.uk providing relevant details, so we can investigate your claim.

\section{OPEN ACCESS}




\title{
Sodium amphibole in the post-glaucophane high-pressure domain: The role of eckermannite
}

\author{
Harriet Howe ${ }^{1}$, Alison R. PaWley ${ }^{1, *}$, AND Mark D. WelCh ${ }^{2}$
}

${ }^{1}$ School of Earth and Environmental Sciences, University of Manchester, Manchester M13 9PL, U.K. ${ }^{2}$ Department of Earth Sciences, Natural History Museum, London SW7 5BD, U.K.

\begin{abstract}
An amphibole close to eckermannite in composition, ideally $\mathrm{Na}_{3} \mathrm{Mg}_{4} \mathrm{AlSi}_{8} \mathrm{O}_{22}(\mathrm{OH})_{2}$, was encountered in experiments on a bulk composition close to that of glaucophane at $6.2 \mathrm{GPa}, \sim 550-650{ }^{\circ} \mathrm{C}$. The synthetic amphibole has an average composition corresponding to ${ }^{\mathrm{A}} \mathrm{Na}_{0.96}{ }^{\mathrm{B}}\left(\mathrm{Na}_{1.80} \mathrm{Mg}_{0.20}\right)^{\mathrm{C}}\left(\mathrm{Mg}_{4} \mathrm{Al}\right)^{\mathrm{T}}\left(\mathrm{Si}_{7.85} \mathrm{Al}_{0.15}\right)$ $\mathrm{O}_{22}(\mathrm{OH})_{2}$. This composition is displaced from that of end-member eckermannite by exchange vectors $+0.15{ }^{\mathrm{B}} \mathrm{Mg}^{\mathrm{T}} \mathrm{Al}^{\mathrm{B}} \mathrm{Na}_{-1}{ }^{\mathrm{T}} \mathrm{Si}_{-1}$ and $+0.05{ }^{\mathrm{A}} \square^{\mathrm{B}} \mathrm{Mg}^{\mathrm{A}} \mathrm{Na}_{-1}{ }^{\mathrm{B}} \mathrm{Na}_{-1}(\square=$ vacant site). In terms of end-members, it corresponds to $80 \%$ eckermannite $+15 \%$ Mg-katophorite, $\mathrm{Na}(\mathrm{NaMg})\left(\mathrm{Mg}{ }_{4} \mathrm{Al}\right)\left(\mathrm{Si}_{7} \mathrm{Al}\right) \mathrm{O}_{22}(\mathrm{OH})_{2},+5 \%$ $\mathrm{Mg}$-winchite, $(\mathrm{NaMg})\left(\mathrm{Mg}_{4} \mathrm{Al}\right) \mathrm{Si}_{8} \mathrm{O}_{22}(\mathrm{OH})_{2}$, and as such is essentially binary. The absence of a glaucophane component implies that the stability of sodium amphibole at very high pressures ( $>4 \mathrm{GPa})$ involves eckermannitic rather than glaucophanic compositions. The stabilization of the eckermannite-pyrope tie line allows this highly Na-rich amphibole to occur even in bulk compositions that are not particularly $\mathrm{Na}$-rich. In blueschist facies metabasites, it is possible that eckermannite forms by the reaction 9 jadeite +7 talc $\rightarrow 3$ eckermannite +3 pyrope +13 coesite $+4 \mathrm{H}_{2} \mathrm{O}$, above the stability limit of glaucophane that is defined by the reaction glaucophane $\rightarrow 2$ jadeite + talc.
\end{abstract}

Keywords: Glaucophane, eckermannite, high pressure, blueschist, subduction

\section{INTRODUCTION}

Eckermannite is a rare member of the sodium amphibole group, having an ideal formula $\mathrm{Na}_{3} \mathrm{Mg}_{4} \mathrm{AlSi}_{8} \mathrm{O}_{22}(\mathrm{OH})_{2}$, with $\mathrm{Na}$ filling the A and $\mathrm{M}(4)$ sites. The only occurrence reported in the literature is from the Jade Mine Tract, Myanmar, a serpentinite mélange containing tectonic blocks and veins of jadeitite (Oberti et al. 2015). Eckermannite from this locality is interpreted as having a metasomatic origin from interaction of sodium-rich fluids with serpentinite, while the presence of jadeite indicates high-pressure, low-temperature conditions, estimated at between 1.0 and $1.5 \mathrm{GPa}$, and 300 to $450{ }^{\circ} \mathrm{C}$ (Shi et al. 2012). All previously described eckermannitic amphiboles are associated with alkaline igneous rocks such as syenites and carbonatites. However, these amphiboles are enriched in $\mathrm{Fe}, \mathrm{Li}$, and/or $\mathrm{F}$, and thus the former holotype from the Norra Kärr nepheline syenite, Sweden, has been reclassified as fluoro-leakeite, and characterization of the eckermannite from the Jade Mine Tract has resulted in a new holotype (Oberti et al. 2015).

The apparent restriction of eckermannite to high-pressure rocks indicates that it is a potential blueschist-facies sodium amphibole. However, its stability and phase relations are unknown. Previous attempts to synthesize eckermannite at low pressures have not been successful: Raudsepp et al. (1991) obtained a 98\% amphibole product at $0.2 \mathrm{GPa}$ and $817^{\circ} \mathrm{C}$; however, the amphibole was not eckermannite, but an A-site empty amphibole inferred to be a solid solution between $\mathrm{NaMg}_{5} \mathrm{AlSi}_{8} \mathrm{O}_{22}(\mathrm{OH})_{2}$ and glaucophane.

Previous high-pressure experimental studies of the phase relations of sodium amphiboles have, unsurprisingly, focused on glaucophane, $\mathrm{Na}_{2} \mathrm{Mg}_{3} \mathrm{Al}_{2} \mathrm{Si}_{8} \mathrm{O}_{22}(\mathrm{OH})_{2}$, the most common

\footnotetext{
*E-mail: alison.pawley@manchester.ac.uk
}

blueschist-facies amphibole. Consistent results have been obtained from synthesis experiments on the bulk composition of glaucophane (Koons 1982; Tropper et al. 2000), its fluorine analog $\mathrm{Na}_{2} \mathrm{Mg}_{3} \mathrm{Al}_{2} \mathrm{Si}_{8} \mathrm{O}_{22} \mathrm{~F}_{2}$ (Welch and Graham 1992) and the closely related amphibole nyböite $\mathrm{Na}_{3} \mathrm{Mg}_{3} \mathrm{Al}_{2} \mathrm{Si}_{7} \mathrm{AlO}_{22}(\mathrm{OH})_{2}$ (Pawley 1992). All studies produced an essentially binary glaucophane-nyböite amphibole that is nyböite-rich at $P<2 \mathrm{GPa}$ and evolves toward glaucophane at $2.5-3 \mathrm{GPa}\left(600-800^{\circ} \mathrm{C}\right)$, primarily by the coupled substitution ${ }^{\mathrm{A}} \square^{\mathrm{T}} \mathrm{Si}^{\mathrm{A}} \mathrm{Na}_{-1}{ }^{\mathrm{T}} \mathrm{Al}_{-1}(\square=$ vacant $\mathrm{A}$ site).

The high-pressure limit of glaucophane stability is governed by the reaction glaucophane $\rightarrow$ jadeite + talc. The position of this reaction has been determined in reversal experiments by Corona et al. (2013) using a synthetic amphibole approaching end-member glaucophane in composition: ${ }^{\mathrm{A}} \mathrm{Na}_{0.08}{ }^{\mathrm{B}}\left(\mathrm{Na}_{1.83} \mathrm{Mg}_{0.17}\right)^{\mathrm{C}}\left(\mathrm{Mg}_{3.12} \mathrm{Al}_{1.88}\right)$ ${ }^{\mathrm{T}}\left(\mathrm{Si}_{7.89} \mathrm{Al}_{0.11}\right) \mathrm{O}_{22}(\mathrm{OH})_{2}$. The linear reaction boundary was located at $2.6 \mathrm{GPa} / 600{ }^{\circ} \mathrm{C}$ to $3.1 \mathrm{GPa} / 700{ }^{\circ} \mathrm{C}$. Data on the stability of sodium amphibole above this reaction are scarce. Here we report the synthesis of eckermannite at $6.2 \mathrm{GPa}$ and $550-650{ }^{\circ} \mathrm{C}$, and we show that it could be a significant post-glaucophane phase in subducted metabasites, which gives it the potential to store $\mathrm{Na}$, water, and trace elements in deeply subducted oceanic crust.

\section{EXPERIMENTAL METHODS}

\section{Synthesis experiments}

Compositions of phases relevant to this study are shown in Figure 1. The starting material for the experiments was a mixture of synthetic brucite, $\mathrm{Mg}(\mathrm{OH})_{2}$, ground silica glass and a previously prepared gel of jadeite composition, with the bulk composition $\mathrm{Na}_{2.1} \mathrm{Mg}_{4.9} \mathrm{Al}_{2.1} \mathrm{Si}_{6.95} \mathrm{O}_{23}+$ excess $\mathrm{H}_{2} \mathrm{O}$. All experiments were run in a multi-anvil apparatus, using an 18/12 sample assembly (18 mm octahedron edge length, $12 \mathrm{~mm}$ truncated edge lengths on the tungsten carbide cubes). The first experiment was intended to investigate the incorporation of $\mathrm{Na}$ and $\mathrm{Al}$ into the $10-\AA$ phase. It was run at $6.2 \mathrm{GPa}, 77 \mathrm{~h}$, and $510-620^{\circ} \mathrm{C}$ (the large temperature uncertainty 
was due to a broken thermocouple). However, no 10 - $\AA$ phase was produced, and instead amphibole was formed, together with jadeite + coesite + pyrope. Another three experiments were then run for further exploration of amphibole stability. They were also run at $6.2 \mathrm{GPa}$, with temperatures in the range $570-690^{\circ} \mathrm{C}$ (thermocouple breakages occurred in another two of these experiments) and run durations between 48 and $100 \mathrm{~h}$. Run products were identified using powder XRD. All runs produced amphibole \pm jadeite \pm pyrope \pm coesite \pm sheet silicate. Water was present in excess in all runs. Amphibole was most abundant in Experiment 2, where it coexisted with pyrope + sheet silicate + coesite.

The amphibole crystals from all experiments are acicular, with diameters $<0.01 \mathrm{~mm}$ and lengths of up to $0.15 \mathrm{~mm}$ (Fig. 2a). High-resolution transmissionelectron microscopy (HRTEM) shows no evidence of any visible defects in the crystals (Fig. 2b). The compositions of amphibole crystals from Experiment 2 were determined by electron-microprobe analysis (EMPA) using a Cameca SX100 Electron Microprobe, operated at $15 \mathrm{keV}$ and $20 \mathrm{nA}$, and with the following standards: fayalite $(\mathrm{Si})$, periclase $(\mathrm{Mg})$, jadeite $(\mathrm{Na})$, and corundum $(\mathrm{Al})$. The average of 10 electronmicroprobe spot analyses is (wt\%) $58.83 \mathrm{SiO}_{2}, 7.23 \mathrm{Al}_{2} \mathrm{O}_{3}, 21.02 \mathrm{MgO}$, and 10.62 $\mathrm{Na}_{2} \mathrm{O}$, which corresponds to the structural formula ${ }^{\mathrm{A}} \mathrm{Na}_{0.96}{ }^{\mathrm{B}}\left(\mathrm{Na}_{1.80} \mathrm{Mg}_{0.20}\right)^{\mathrm{C}}\left(\mathrm{Mg}_{4} \mathrm{Al}\right)$ ${ }^{\mathrm{T}}\left(\mathrm{Si}_{7.85} \mathrm{Al}_{0.15}\right) \mathrm{O}_{22}(\mathrm{OH})_{2}$. In terms of amphibole end-member components, this formula is $80 \%$ eckermannite, $15 \% \mathrm{Mg}$-katophorite, and $5 \% \mathrm{Mg}$-winchite. The identification of the last two components is made with reference to the most recent nomenclature of Hawthorne et al. (2012). We point out that these two amphibole end-members have no natural counterparts, and so for ease of discussion we have named them to be consistent with Hawthorne et al. (2012) for katophorite ${ }^{\mathrm{A}} \mathrm{Na}^{\mathrm{B}}(\mathrm{NaCa})^{\mathrm{C}}\left(\mathrm{Mg}_{4} \mathrm{Al}\right)$ ${ }^{\mathrm{T}} \mathrm{Si}_{7} \mathrm{AlO}_{22}(\mathrm{OH})_{2}$ and winchite ${ }^{\mathrm{A}} \square^{\mathrm{B}}(\mathrm{NaCa})^{\mathrm{C}}\left(\mathrm{Mg}_{4} \mathrm{Al}\right)^{\mathrm{T}} \mathrm{Si}_{8} \mathrm{O}_{22}(\mathrm{OH})_{2}$, recognizing that the "Mg-" identifier denotes $\mathrm{Mg}$ replacing $\mathrm{Ca}$ at the $\mathrm{M}(4)$ site.

The sheet silicate was identified as aspidolite, $\mathrm{NaMg}_{3} \mathrm{AlSi}_{3} \mathrm{O}_{10}(\mathrm{OH})_{2}$, from its distinctive hydration state at room temperature (Carman 1974). By analogy with previous experiments in which aspidolite was formed (Pawley 1992), the sheet silicate may show solid solution toward preiswerkite, $\mathrm{NaMg}_{2} \mathrm{Al}_{3} \mathrm{Si}_{2} \mathrm{O}_{10}(\mathrm{OH})_{2}$.

\section{X-ray diffraction}

Numerous crystals of synthetic eckermannite were screened by single-crystal $\mathrm{X}$-ray diffraction (SCXRD) to check diffraction quality using an Xcalibur four-circle diffractometer equipped with an EoS area detector and operated at $45 \mathrm{kV}, 40 \mathrm{~mA}$ with $\mathrm{Mo} K \alpha$ radiation $(\lambda=0.71073 \AA)$. However, all crystals were very weakly diffracting due to their extreme thinness $(0.005 \mathrm{~mm})$ and the presence of only weak X-ray scatterers $(\mathrm{O}, \mathrm{Na}, \mathrm{Mg}, \mathrm{Al}, \mathrm{Si})$. A full data collection to $27.5^{\circ} \theta$ using a frame-time of $240 \mathrm{~s}$, was attempted on the best crystal, but the reflection merging was very poor $\left(R_{\mathrm{int}}=0.26\right)$, again due to the weakness of the reflections $\left(R_{\sigma}=0.414\right)$ and extremely acicular nature of the crystal. However, sufficient stronger reflections having $I>7 \sigma(I)$ allowed derivation of precise unit-cell parameters (monoclinic, space group $C 2 / \mathrm{m}$ ): $a=9.726(4), b=17.757(6), c=5.278(2) \AA, \beta=103.58(3)^{\circ}$, and $V=886.0(6) \AA^{3}$.

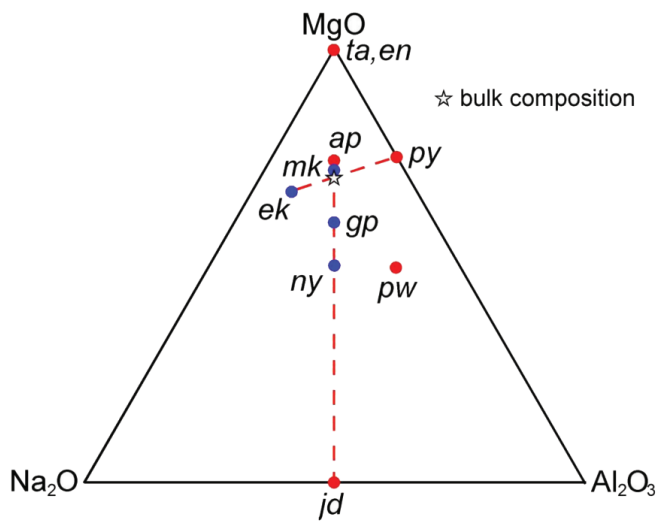

FIGURE 1. Compositions of phases relevant to eckermannite and glaucophane stability at high pressure. Projection from $\mathrm{SiO}_{2}$ and $\mathrm{H}_{2} \mathrm{O}$ onto $\mathrm{Na}_{2} \mathrm{O}-\mathrm{MgO}-\mathrm{Al}_{2} \mathrm{O}_{3}$. Abbreviations: ap = aspidolite, ek = eckermannite, en = enstatite, $\mathrm{gp}=$ glaucophane, $\mathrm{jd}=$ jadeite, $\mathrm{mk}=\mathrm{Mg}$-katophorite, ny $=$ nyboite, $\mathrm{pw}=$ preiswerkite, $\mathrm{py}=$ pyrope, $\mathrm{ta}=$ talc. The experimental bulk composition lies on the intersection of the ek-py and ap-jd joins (shown by dashed lines). (Color online.)
A quasi-powder pattern for an aggregate of eckermannite crystals from Experiment 2 mounted on a $0.01 \mathrm{~mm}$ diameter carbon-fiber support was collected using a Rigaku Oxford Diffraction RAPIDII curved-imaging-plate diffractometer with graphite-monochromated $\mathrm{Cu} K \alpha$ radiation $(45 \mathrm{kV}, 20 \mathrm{~mA})$. A Gandolfi-type randomized movement was achieved by rotation around the $\varphi$ and $\omega$ axes. The General Structure Analysis System (GSAS, Toby and Von Dreele 2013) was used for Rietveld refinement. The starting structural model used was taken from Oberti et al. (2015) for eckermannite from Myanmar with the structural formula ${ }^{\mathrm{A}}\left(\mathrm{Na}_{0.87} \mathrm{~K}_{0.06}\right)_{\Sigma 0.93}$ ${ }^{\mathrm{B}}\left(\mathrm{Na}_{1.89} \mathrm{Ca}_{0.11}\right)_{\Sigma 2.00}{ }^{\mathrm{C}}\left(\mathrm{Mg}_{3.87} \mathrm{Fe}_{0.09}^{2+} \mathrm{Mn}_{0.01} \mathrm{Fe}_{0.38}^{3+} \mathrm{Al}_{0.62}\right)_{\Sigma 4.97}{ }^{\mathrm{T}} \mathrm{Si}_{8.00} \mathrm{O}_{22}{ }^{\mathrm{W}}\left(\mathrm{F}_{0.03} \mathrm{OH}_{1.97}\right)$. Unit-cell parameters were refined along with the coefficients of a cosine series to model background and Gaussian and Lorentzian line shape parameters. Preferred orientation was also refined, but found to be negligible. An attempt to refine atom coordinates and isotropic atom-displacement parameters was successful for some sites, but failed to converge for most. Consequently, atom coordinates and atom-displacement parameters were not refined, but fixed at the values reported by Oberti et al. (2015). The refined unit-cell parameters are in close agreement with those obtained by SCXRD: $a=9.7278(4), b=17.7431(8), c=5.2806(2) \AA, \beta=103.541(3)^{\circ}$, and $V=886.10(7)$ $\AA^{3}$. Final agreement indices at convergence are $R_{\mathrm{p}}=0.031$ and $w R_{\mathrm{p}}=0.043$. The fit of the refined pattern is shown in Figure 3.

\section{Raman spectroscopy}

The unpolarized Raman spectrum of a single crystal of eckermannite is shown in Figure 4. It comprises an intense peak with a Raman shift of $3729 \mathrm{~cm}^{-1}$ and a very minor peak at $3629 \mathrm{~cm}^{-1}$. The $3729 \mathrm{~cm}^{-1}$ peak is characteristic of $\mathrm{OH}$ associated with an A site occupied by $\mathrm{Na}$ and associated with a single local arrangement $\mathrm{Mg}(1) \mathrm{Mg}(1)$ $\mathrm{Mg}(3)-\mathrm{OH}{ }^{\cdots A} \mathrm{Na}$ (Della Ventura et al. 1997). The separation by $100 \mathrm{~cm}^{-1}$ between the two peaks is more than the difference between A-site full and A-site empty local arrangements (usually $60 \mathrm{~cm}^{-1}$ ) and suggests contamination by minor sheet silicate (preiswerkite has its main peak at $3628 \mathrm{~cm}^{-1}$, Tlili et al. 1989). The absence of any other $\mathrm{OH}$ peaks indicates that the $\mathrm{M}(1,3)$ sites are occupied only by $\mathrm{Mg}$ and requires that $\mathrm{Al}$ is fully ordered at $\mathrm{M}(2)$. As such, this spectrum is consistent with the average formula determined by EMPA.

\section{DISCUSSION}

We have shown that sodium amphibole coexisting with jadeite, pyrope, and coesite at $6.2 \mathrm{GPa}$ and $550-650^{\circ} \mathrm{C}$ is highly eckermannitic $(80 \mathrm{~mol} \%)$. The bulk composition used allows for ternary or higher-order solid solution in amphibole. However, we find that the amphibole has an essentially binary ek-mk composition. While synthesis experiments do not, of course, demonstrate thermodynamic stability, previous synthesis studies (Koons 1982; Welch and Graham 1992; Pawley 1992; Tropper et al. 2000; Corona and Jenkins 2007) show convincing systematic trends in amphibole composition as a function of $P$ and $T$. It seems reasonable, therefore, to infer that eckermannite-rich amphibole, as encountered in this study, is likely to be stable at $6.2 \mathrm{GPa}, 600{ }^{\circ} \mathrm{C}$, rather than being a metastable product of the synthesis method.

The range of assemblages produced in our experiments probably reflects the nominal bulk composition lying on both the eckermannite-pyrope-coesite and jadeite-aspidolite-coesite joins (Fig. 1), such that small variations in bulk composition and temperature both between experiments and, possibly, within a single experiment, resulted in varying proportions of eckermannite and other phases.

Our synthesis pressure is $3 \mathrm{GPa}$ higher than the upper baric limit of glaucophane stability of about $3.2 \mathrm{GPa}$ at $700{ }^{\circ} \mathrm{C}$ (Corona et al. 2013). The fact that our sample was synthesized from a bulk composition not far from that of end-member glaucophane raises the question as to why eckermannite has not been synthesized in previous studies of glaucophanic amphiboles. The answer may lie in the bulk compositions used previously, all of which had $\mathrm{Na}: \mathrm{Al}=1: 1$. In most cases, the amphiboles had compositions with a Na:Al ratio deviating very little from $1: 1$, and coexisted with quartz, jadeite, and either talc or aspidolite, also with $\mathrm{Na}: \mathrm{Al}=1: 1$, 

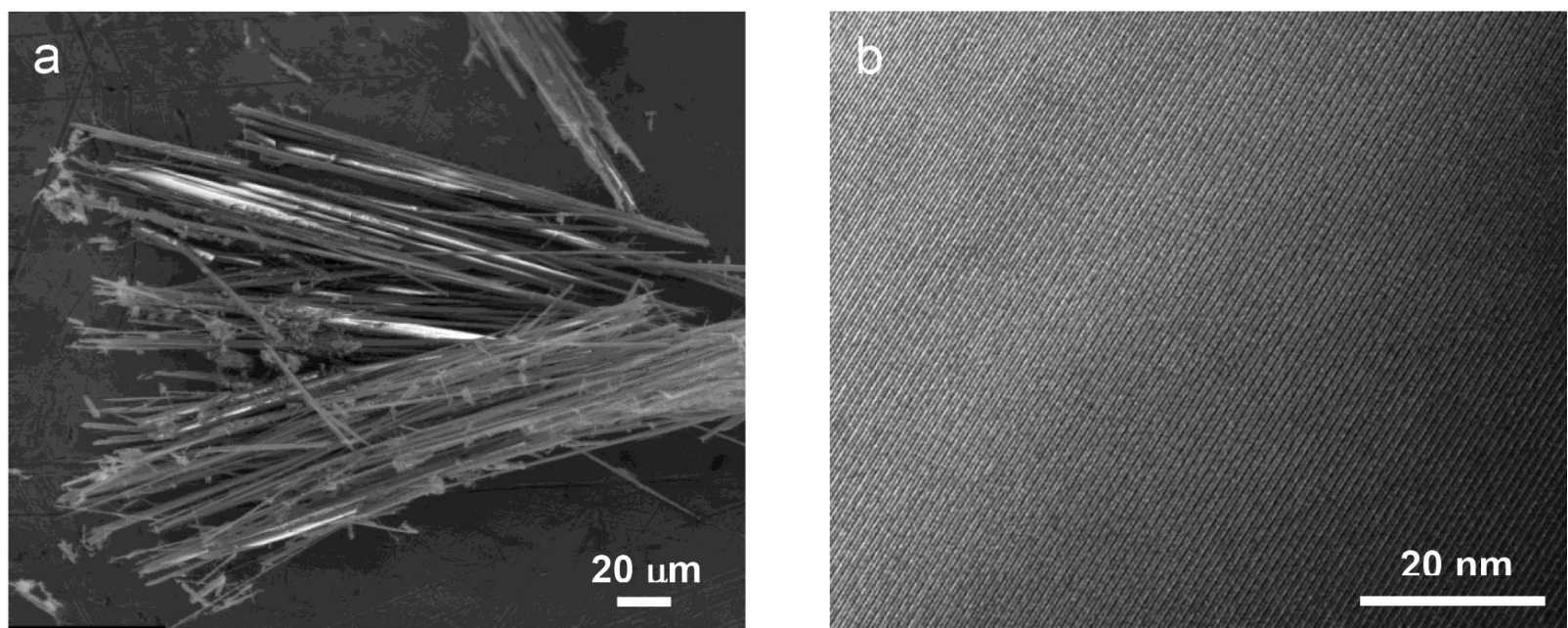

FIGURE 2. (a) Secondary-electron image of eckermannite crystals from Experiment $2\left(6.2 \mathrm{GPa}, 580-670{ }^{\circ} \mathrm{C}\right)$. (b) Bright-field HRTEM image of an eckermannite crystal from Experiment $1\left(6.2 \mathrm{GPa}, 510-620^{\circ} \mathrm{C}\right)$ viewed along $a^{*}$ and showing $(0 \mathrm{k} 0)$ fringes, showing the characteristic amphibole double-chain structure.

indicating that the amphibole composition was buffered onto the jadeite-talc-quartz plane (Fig. 1). The only amphiboles to show a significant eckermannite component were synthesized from a silica-undersaturated bulk composition (Pawley 1992), for which the sheet silicate showed solid solution toward aspidolite and preiswerkite. The preiswerkite component allowed the amphibole composition to move off the $\mathrm{Na}: \mathrm{Al}=1$ plane. The maximum eckermannite content in those amphiboles was 0.45 apfu. Therefore, we suggest that at pressures relevant to glaucophane stability, a bulk composition with high $\mathrm{Na}$ :Al would be required to synthesize an amphibole approaching end-member eckermannite. Similarly, in nature eckermannite has so far only been found in rocks of unusually Na-rich compositions.

Our synthesis of eckermannite at 6.2 GPa from a bulk composition with $\mathrm{Na}: \mathrm{Al}=1: 1$, shows that at this pressure, the amphibole composition is no longer buffered onto the jadeite-talc-quartz/ coesite plane, even for silica-saturated compositions (most of our run products coexist with coesite). It is evident that the stabilization of the eckermannite-pyrope tie line at high pressure (Fig. 1)

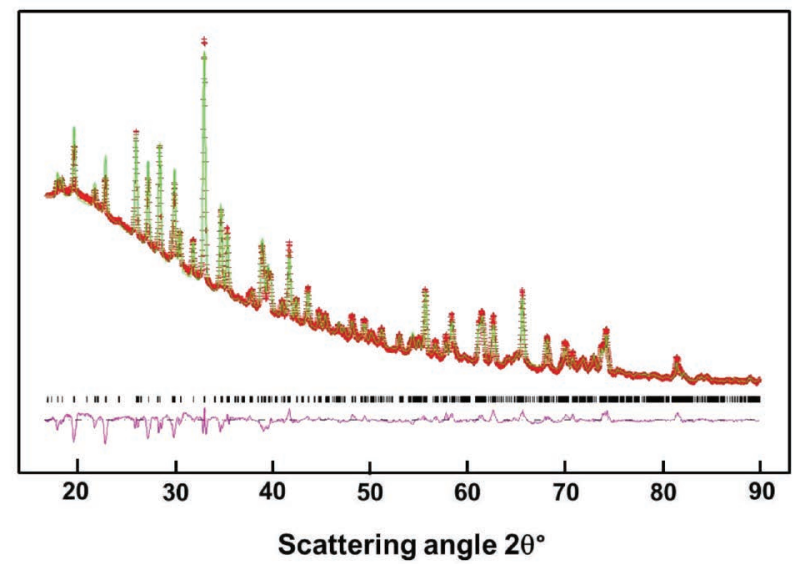

FIGURE 3. Rietveld refinement of eckermannite from Experiment 2. Line markers indicate calculated peak positions. The residual unfitted data are shown below the fitted pattern. (Color online.) is key to its synthesis in a bulk composition with $\mathrm{Na}: \mathrm{Al}=1$, as pyrope is $\mathrm{Al}$ rich and $\mathrm{Na}$ free.

The high-pressure trend of increasing $\mathrm{Na}$ and decreasing $\mathrm{Al}$ that occurs from glaucophane to eckermannite is similar to that observed in recent experimental studies on sodium-rich calcium amphiboles. In experiments simulating metasomatism of the mantle wedge by fluids derived by partial melting of subducted sediment, Pirard and Hermann (2015) produced amphiboles close in composition to the sodium-calcium amphibole katophorite, $\mathrm{Na}_{2} \mathrm{CaMg}_{4} \mathrm{AlSi}_{7} \mathrm{AlO}_{22}(\mathrm{OH})_{2}$, at pressures of 2.5-4.5 GPa, with amphibole breaking down at $950-1000{ }^{\circ} \mathrm{C}$ at $4.5 \mathrm{GPa}$. Amphibole compositions showed an increase in $\mathrm{Na} / \mathrm{Ca}$ toward nyböite with pressure. Mandler and Grove (2016) also observed increasing $\mathrm{Na} / \mathrm{Ca}$ in amphiboles with pressure, in experiments at 2-4 GPa, 950-1100 ${ }^{\circ} \mathrm{C}$ on mantle compositions modified by the addition of $1 \%$ of a metasomatic Na-rich component, which produced pargasitic amphiboles. They also observed a decrease in Al with increasing pressure. Both of these studies produced garnet in higher-pressure experiments ( $>2 \mathrm{GPa})$, indicating that as the $\mathrm{Al}$ content of amphibole decreases with increasing pressure, garnet becomes the main aluminous phase.

These recent studies show that Na-rich amphiboles can be syn-

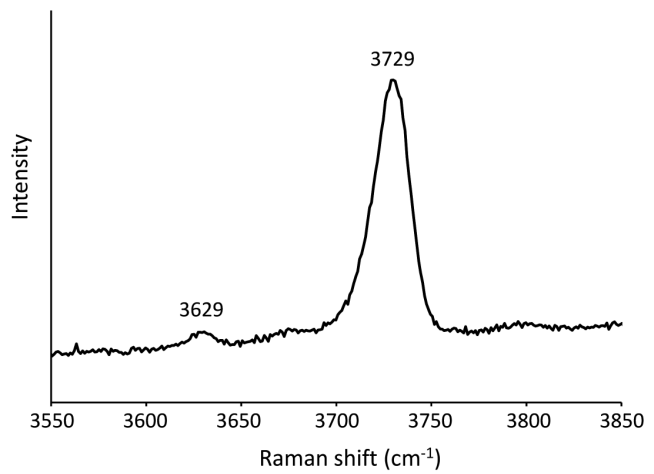

FIGURE 4. Unpolarized Raman spectrum in the $\mathrm{OH}$-stretching region of eckermannite from Experiment 2. 
thesized at pressures up to at least $4.5 \mathrm{GPa}$. Our study takes their stability limit to at least $6 \mathrm{GPa}$. Mandler and Grove (2016) point out that high $\mathrm{Na} / \mathrm{Ca}$ is associated with reduced thermal stability of amphibole, and so eckermannite is likely not to be stable at the high temperatures investigated by Pirard and Hermann (2015) and Mandler and Grove (2016), where katophorite is likely to be the stable amphibole.

An important consequence of the high $\mathrm{Na}$ :Al ratio of eckermannite is that it cannot be decomposed into charge-neutral pyroxene and sheet-silicate components, as there are no pyroxenes or sheet silicates in the NMASH system with $\mathrm{Na}: \mathrm{Al}>1$. For example, polysomatic decomposition of the eckermannite structure leads to $\left[\mathrm{Na}_{2} \mathrm{MgAlSi}_{4} \mathrm{O}_{12}\right]^{-1}$ ("pyroxene") and $\left[\mathrm{NaMg}_{3} \mathrm{Si}_{4} \mathrm{O}_{10}(\mathrm{OH})_{2}\right]^{+1}$ ("sheet silicate") modules. Analogously, polysomatic decomposition of Al-free K-richterite, $\mathrm{KNaCaMg}_{5} \mathrm{Si}_{8} \mathrm{O}_{22}(\mathrm{OH})_{2}$, would result in $\left[\mathrm{NaCaMg}_{2} \mathrm{Si}_{4} \mathrm{O}_{12}\right]^{-1}$ ("pyroxene") and $\left[\mathrm{KMg}_{3} \mathrm{Si}_{4} \mathrm{O}_{10}(\mathrm{OH})_{2}\right]^{+1}$ ("sheet silicate") modules. K-richterite has the highest reported baric stability of any amphibole, having been synthesized at $P>14 \mathrm{GPa}$ at $1000{ }^{\circ} \mathrm{C}$ (Trønnes 2002). A direct consequence of the implied production of energetically unstable charged structure modules is that the usual pressure-stability limit of amphibole defined by the amphibole $=$ pyroxene + sheet-silicate $/$ talc reaction does not occur for K-richterite and eckermannite, and this may be the reason for their exceptionally high baric stabilities.

An alternative polysomatic decomposition reaction for eckermannite can be conceived that involves the triple-chain silicate $\mathrm{Na}_{2} \mathrm{Mg}_{4} \mathrm{Si}_{6} \mathrm{O}_{16}(\mathrm{OH})_{2}$ (Tateyama et al. 1978; Maresch et al. 2009) and jadeite: $\mathrm{Na}_{3} \mathrm{Mg}_{4} \mathrm{AlSi}_{8} \mathrm{O}_{22}(\mathrm{OH})_{2} \rightarrow \mathrm{NaAlSi}_{2} \mathrm{O}_{6}+$ $\mathrm{Na}_{2} \mathrm{Mg}_{4} \mathrm{Si}_{6} \mathrm{O}_{16}(\mathrm{OH})_{2}$. In this case, no charged entities are involved. However, triple-chain silicates have relatively low baric stabilities $(<1 \mathrm{GPa})$ compared with amphiboles, and with increasing pressure and temperature decompose to form unusual $\mathrm{OH}$-rich amphiboles having more than $2 \mathrm{OH}$ pfu (Witte 1975; Maresch et al. 2009). For example, the maximum thermal stability of $\mathrm{Na}_{2} \mathrm{Mg}_{4} \mathrm{Si}_{6} \mathrm{O}_{16}(\mathrm{OH})_{2}$ is $\sim 530^{\circ} \mathrm{C}$ at $0.2 \mathrm{GPa}$; at $1 \mathrm{GPa}$ the limit is $400^{\circ} \mathrm{C}$. Consequently, the decomposition of eckermannite to jadeite and $\mathrm{Na}_{2} \mathrm{Mg}_{4} \mathrm{Si}_{6} \mathrm{O}_{16}(\mathrm{OH})_{2}$ triple-chain silicate is not expected.

\section{IMPLICATIONS}

This study is the first to show that eckermannitic amphibole is the likely stable sodium amphibole that succeeds glaucophane in prograde metabasites in the high- $P /$ low- $T$ domain. As such, it represents an important extension of the baric stability of sodium amphibole. The experiments reported here suggest that eckermannite could be produced by the reaction 9 jadeite +7 talc $\rightarrow 3$ eckermannite +3 pyrope +13 coesite $+4 \mathrm{H}_{2} \mathrm{O}$, with the reactants being available from the decomposition of glaucophanic amphibole.

Previous experimental studies of glaucophane and related amphiboles in the presence of quartz/coesite show that at $P \leq 3.5 \mathrm{GPa}$, all amphiboles have $\mathrm{Na}: \mathrm{Al}=1: 1$ (gp, ny, mk). The present study indicates that at higher pressures, this ratio is expected to change with stabilization of the eckermannite-pyrope tie line, so that $\mathrm{Na}$ and $\mathrm{Al}$ are partitioned differently between minerals in the postglaucophane regime of blueschists, with amphibole becoming increasingly important as a host for $\mathrm{Na}$. We propose that the formation of eckermannite at high pressure does not require additional $\mathrm{Na}$ enrichment of the host rock, simply the presence of jadeite and talc formed by the decomposition of glaucophane.
Consequently, eckermannite is to be expected in metabasites in the post-glaucophane high- $P$ regime.

\section{ACKNOWLEDGMENTS}

This work was supported by a Natural Environment Research Council Ph.D. studentship to Harriet Howe. We thank Heath Bagshaw, Jonathan Fellowes, and John Waters for technical assistance and advice in the analytical labs in Manchester. Reviewers Frank Hawthorne and David Jenkins are thanked for their helpful comments on the manuscript.

\section{REFERENCES CITED}

Carman, J.H. (1974) Synthetic sodium phlogopite and its two hydrates: Stabilities, properties, and mineralogic implications. American Mineralogist, 59, 261-273.

Corona, J.C., and Jenkins, D.M. (2007) An experimental investigation of the reaction: glaucophane +2 quartz $=2$ albite + talc. European Journal of Mineralogy, 19, $147-158$

Corona, J.C., Jenkins, D.M., and Holland, T.J.B. (2013) Constraints on the upper pressure stability of blueschist facies metamorphism along the reaction: glaucophane $=$ talc +2 jadeite in the $\mathrm{Na}_{2} \mathrm{O}-\mathrm{MgO}-\mathrm{Al}_{2} \mathrm{O}_{3}-\mathrm{SiO}_{2}-\mathrm{H}_{2} \mathrm{O}$ system. American Journal of Science, 313, 967-995.

Della Ventura, G., Robert, J-L., Hawthorne, F.C., and Welch, M.D. (1997) Site occupancies in synthetic monoclinic amphiboles: Rietveld refinement and infrared spectroscopy of (nickel, magnesium, cobalt)-richterite. American Mineralogist, 82, 291-301.

Hawthorne, F.C., Oberti, R., Harlow, G.E., Maresch, W.V., Martin, R.F., Schumacher, J.C., and Welch, M.D. (2012) Nomenclature of the amphibole supergroup. American Mineralogist, 97, 2031-2048.

Koons, P.O. (1982) An experimental investigation of the behavior of amphibole in the system $\mathrm{Na}_{2} \mathrm{O}-\mathrm{MgO}-\mathrm{Al}_{2} \mathrm{O}_{3}-\mathrm{SiO}_{2}-\mathrm{H}_{2} \mathrm{O}$ at high pressures. Contributions to Mineralogy and Petrology, 79, 258-267.

Mandler, B.E., and Grove, T.L. (2016) Controls on the stability and composition of amphibole in the Earth's mantle. Contributions to Mineralogy and Petrology, 171, 68-77.

Maresch, W.V., Welch, M.D., Gottschalk, M., Ruthmann, W., Czank, M., and Ashbrook, S.E. (2009) Synthetic amphiboles and triple-chain silicates in the system $\mathrm{Na}_{2} \mathrm{O}$ $\mathrm{MgO}-\mathrm{SiO}_{2}-\mathrm{H}_{2} \mathrm{O}$ : phase characterization, compositional relations and excess $\mathrm{H}$. Mineralogical Magazine, 73, 957-996.

Oberti, R., Boiocchi, M., Hawthorne, F.C., Ball, N.A., and Harlow, G.E. (2015) Eckermannite revised: The new holotype from the Jade Mine Tract, Myanmar - crystal structure, mineral data, and hints on the reasons for the rarity of eckermannite. American Mineralogist, 100, 909-914.

Pawley, A.R. (1992) Experimental study of the compositions and stabilities of synthetic nyböite and nyböite-glaucophane amphiboles. European Journal of Mineralogy, 4, 171-192.

Pirard, C., and Hermann, J. (2015) Experimentally determined stability of alkali amphibole in metasomatised dunite at sub-arc pressures. Contributions to Mineralogy and Petrology, 169, 1-26.

Raudsepp, M., Turnock, A.C., and Hawthorne, F.C. (1991) Amphibole synthesis at low pressure: what grows and what doesn't. European Journal of Mineralogy, 3, 983-1004.

Shi, G., Harlow, G.E., Wang, J., Wang, J., Ng, E., Wang, X., Cao, S., and Cui, W. (2012) Mineralogy of jadeitite and related rocks from Myanmar: a review with new data. European Journal of Mineralogy, 24, 345-370.

Tateyama, H., Shimoda, S., and Sudo, T. (1978) Synthesis and crystal structure of a triple chain silicate, $\mathrm{Na}_{2} \mathrm{Mg}_{4} \mathrm{Si}_{6} \mathrm{O}_{16}(\mathrm{OH})_{2}$. Contributions to Mineralogy and Petrology, 66, 149-156.

Tlili, A., Smith, D.C., Beny, J.-M., and Boyer, H. (1989) A Raman microprobe study of natural micas. Mineralogical Magazine, 53, 165-179.

Toby, B.H., and Von Dreele, R.B. (2013) GSAS-II: the genesis of a modern open-source all-purpose crystallography software package. Journal of Applied Crystallography, 46, $544-549$.

Trønnes, R.G. (2002) Stability range and decomposition of potassic richterite and phlogopite end members at 5-15 GPa. Mineralogy and Petrology, 74, 129-148.

Tropper, P., Manning, C.E., Essene, E.J., and Kao, L.-S. (2000) The compositional variation of synthetic sodium amphiboles at high and ultra-high pressures. Contributions to Mineralogy and Petrology, 139, 146-162.

Welch, M.D., and Graham, C.M. (1992) An experimental study of glaucophanic amphiboles in the system $\mathrm{Na}_{2} \mathrm{O}-\mathrm{MgO}-\mathrm{Al}_{2} \mathrm{O}_{3}-\mathrm{SiO}_{2}-\mathrm{SiF}_{4}$ (NMASF): some implications for glaucophane stability in natural and synthetic systems at high temperatures and pressures. Contributions to Mineralogy and Petrology, 111, 248-259.

Witte, P. (1975) Synthesis and stability of amphibole phases and anhydrous Na-Mgsilicates in the system $\mathrm{Na}_{2} \mathrm{O}-\mathrm{MgO}-\mathrm{SiO}_{2}-\mathrm{H}_{2} \mathrm{O}$, the compatibility relationships in the Si-rich part of the quaternary system above $600^{\circ} \mathrm{C}$ in the pressure range $1 \mathrm{~atm}-5 \mathrm{~kb}$ $\left(\mathrm{H}_{2} \mathrm{O}\right)$ and their petrological significance]. Ph.D. thesis, Ruhr-University Bochum, Germany, 256 pp.

MANUSCRIPT RECEIVED NOVEMBER 20, 2017

MANUSCRIPT ACCEPTED FEBRUARY 28, 2018

MANUSCRIPT HANDLED BY THOMAS MUELLER 